\title{
PENGARUH TIPE KEPRIBADIAN, PENGALAMAN DAN PENERIMAAN PERILAKU DISFUNGSIONAL TERHADAP AUDIT JUDGMENT
}

\author{
Fikri Ismail \\ Ikatan Akuntan Indonesia \\ fikriismail.sukses@gmail.com
}

\begin{abstract}
This research was aimed to obtain empirical evident whether there is any effect of personality type, auditor's experience and acceptance of dysfunctional behavior toward audit judgment taken by auditor. This research was carried out in DKI Jakarta with respondent from auditors who work in Public Accountant Office in DKI Jakarta. The sampling technique is used convenience sampling. Data is collected using questionnaires distributed as 79 and only 51 questionnaires that can be processed. Data analysis using multiple linear regression. The results of this study showed that : (1) personality type didn't has significant effects on audit judgment. (2) auditor's experience has significant effects on audit judgment. (3) acceptance of dysfunctional behavior has significant effects on audit judgment. (4) personality type, auditor's experience and acceptance of dysfunctional behavior have significant effects on audit judgment simultaneously.
\end{abstract}

Keywords: personality type, auditor's experience, acceptance of dysfunctional behavior, audit judgment

\begin{abstract}
Abstrak. Penelitian ini bertujuan untuk memperoleh bukti empiris apakah terdapat pengaruh dari tipe kepribadian, pengalaman dan penerimaan perilaku disfungsional terhadap audit judgment yang diambil oleh auditor. Penelitian ini dilakukan di DKI Jakarta dengan responden dari auditor yang bekerja di Kantor Akuntan Publik (KAP) di DKI Jakarta. Teknik pengambilan sampel menggunakan metode convenience sampling. Data dikumpulkan menggunakan pendistribusian kuisioner sebanyak 79 dan hanya 51 kuisioner yang dapat diproses. Metode analisis data menggunakan regresi linear berganda. Hasil dari studi ini menunjukan bahwa: (1) tipe kepribadian tidak berpengaruh signifikan terhadap audit judgment. (2) pengalaman berpengaruh signifikan terhadap audit judgment. (3) penerimaan perilaku disfungsional berpengaruh signifikan terhadap audit judgment. (4) tipe kepribadian, pengalaman dan penerimaan perilaku disfungsional berpengaruh signifikan terhadap audit judgment secara simultan.
\end{abstract}

Kata Kunci: tipe kepribadian, pengalaman auditor, penerimaan perilaku disfungsional, audit judgment. 


\section{PENDAHULUAN}

Akuntan (auditor) merupakan suatu profesi yang salah satu tugasnya adalah melaksanakan audit terhadap laporan keuangan sebuah entitas dan memberikan opini atau pendapat terhadap saldo akun dalam laporan keuangan apakah telah disajikan secara wajar sesuai dengan standar akuntansi keuangan atau prinsip akuntansi yang berlaku umum; dan standar atau prinsip tersebut diterapkan secara konsisten (Wibowo, 2010). Belakangan ini profesi akuntan publik menjadi sorotan banyak pihak. Sorotan tajam diberikan karena akuntan publik dianggap memiliki kontribusi dalam banyak kasus kebangkrutan perusahaan. Profesionalisme akuntan seolah dijadikan kambing hitam dan harus memikul tanggung jawab pihak lain yang seharusnya bertanggungjawab atas kegagalan itu (Heli, 2004 dalam Arum, 2008).

Pandangan skeptis terhadap auditor ini memang cukup beralasan, karena banyak sekali kejahatan akuntansi yang terjadi belakangan ini yang melibatkan para auditor. Sebagai contoh adalah kasus Dell Computer di tahun 2007 yang telah diselidiki ternyata sering memanipulasi akrual saldo rekening untuk memenuhi ekspektasi keuangan kuartal Wall Street pada tahun sebelumnya. Kemudian skandal Satyam Computer Service di tahun 2009 yang merupakan skandal bisnis terbesar di India yang disebabkan oleh peningkatan kas dan saldo bank lebih dari \$1,5 miliar yang dibesar-besarkan pada posisi debitur sebesar \$100 juta dan kewajiban understated sebesar \$ 250 juta demi kepentingan pemiliknya. Di Indonesia juga terjadi kejahatan dalam bidang akuntansi yang di lakukan oleh PT. Kimia Farma atas laporan keuangan tahun 2001 yang terbukti melaporkan overstated laba bersih sebesar Rp 32 miliar, dan skandal Raden Motor Jambi di tahun 2009 yang terlibat kasus korupsi dalam kredit macet dibantu seorang akuntan publik membuat laporan keuangan perusahaan untuk mendapatkan pinjaman modal senilai Rp 52 miliar dari suatu bank. Kasus-kasus tersebut memang membuktikan betapa akuntan publik gagal menjalankan perannya sebagai auditor independen. Tugas seorang auditor adalah melakukan penilaian atau judgment terhadap laporan keuangan dan berbagai kecurangan yang muncul dalam laporan keuangan dan lain sebagainya. Namun begitu, profesi auditor adalah profesi yang sangat riskan sebab terkadang seorang auditor tidak bekerja sesuai dengan standar profesional auditor yang ada, melainkan 
sesuai dengan keinginan klien yang hanya menguntungkan pihak klien. Hal ini jelas menunjukan bahwa sebenarnya auditor tidak melakukan audit judgment dengan sebagai mana mestinya.

Miller (2009) dalam Kristianti (2012) menjelaskan faktor-faktor yang akan berpengaruh dalam pengambilan keputusan adalah: jenis kelamin, peranan pengambilan keputusan, dan keterbatasan kemampuan. Dalam peranan pengambilan suatu keputusan individu dipengaruhi oleh tiga faktor utama yaitu nilai individu, kepribadian, dan kecenderungan dalam pengambilan resiko.

Turban et al., (2005) menyebutkan bahwa tipe kepribadian, gender dan kondisi manusia mempengaruhi pengambilan keputusan seseorang. Tipe kepribadian mempengaruhi orientasi umum kearah pencapaian tujuan, pemilihan alternatif, tindakan terhadap risiko, dan reaksi dibawah tekanan. Tipe kepribadian mempengaruhi kemampuan para pengambil keputusan untuk memproses sejumlah besar informasi, tekanan waktu, dan ketahanan diri. Ia juga mempengaruhi aturan dan pola komunikasi dari seorang pengambilan keputusan.

Menurut Allport (Suryabrata, 1995: 248) dalam Kristianti (2012) kepribadian adalah organisasi dinamis dan sistem psikofisik individu yang menentukan tingkah laku dan pemikiran individu secara khas. Kepribadian juga merupakan sesuatu yang terdapat dalam diri individu yang membimbing dan memberi arahan pada tingkah laku individu. Sehingga, tipe kepribadian juga turut mempengaruhi cara pengambilan keputusan.

Pengalaman adalah keseluruhan pelajaran yang dipetik oleh seseorang dari peristiwa yang dialami dalam perjalanan hidupnya (Anoraga, 1995:47 dalam Justiana, 2010). Pengalaman berdasarkan lama bekerja merupakan pengalaman auditor yang dihitung berdasarkan satuan waktu/tahun. Sehingga auditor yang telah lama bekerja sebagai auditor dapat dikatakan sebagai auditor berpengalaman. Semakin lama bekerja menjadi auditor, maka akan memperluas pengetahuan auditor dibidang akuntansi dan auditing. Pengalaman audit diperoleh auditor selama mereka mengerjakan penugasan auditnya. Pengalaman akan diperoleh jika prosedur penugasan dan supervisor berjalan dengan baik. Prosedur penugasan adalah prosedur yang menjamin terjadinya keseimbangan antara kebutuhan, keahlian, pengembangan dan pemanfataan personel dalam pelaksanaan perikatan (IAPI, 2009). 
Penerimaan perilaku disfungsional merupakan suatu bentuk reaksi terhadap lingkungan atau semisal sistem pengendalian (Otley dan Pierce, 1995; Lightner et al., 1983; Alderman dan Deitrick, 1982 dalam Donelly et al., 2003). Sistem pengendalian yang berlebihan akan menyebabkan terjadinya konflik dan mengarah pada perilaku disfungsional. Donelly et al., (2003) menyatakan bahwa sikap auditor yang menerima perilaku disfungsional merupakan indikator perilaku disfungsional aktual. Penerimaan atas perilaku disfungsional akan mempengaruhi proses audit yang akan dilakukan, dengan demikian maka hal ini dapat mempengaruhi audit judgment seorang auditor.

\section{METODOLOGI PENELITIAN}

Penelitian ini yang dijadikan tempat penelitian adalah beberapa Kantor Akuntan Publik (KAP) di DKI Jakarta dan penelitian ini dilakukan pada bulan Oktober tahun 2014. Populasi merupakan keseluruhan kelompok orang, kejadian, atau hal minat yang ingin peneliti investigasi. Populasi dalam penelitian ini adalah auditor eksternal pada suatu Kantor Akuntan Publik (KAP) yang berada di wilayah Jakarta. Dasar pemilihan sampel ini menggunakan metode convenience sampling, yaitu memilih sampel dari elemen populasi yang datanya mudah diperoleh peneliti. Elemen populasi yang dipilih sebagai subjek sampel adalah tidak terbatas sehingga peneliti memiliki kebebasan untuk memilih sampel yang paling cepat dan mudah (Indriantoro dan Supomo, 2009:130). Metode analisis data yang digunakan oleh peneliti adalah statistik deskriptif, uji kualitas data, uji asumsi klasik dan uji hipotesis.

Hipotesis dalam penelitian ini diuji dengan menggunakan analisis regresi berganda. Model regresi berganda bertujuan untuk memprediksi besar variabel dependen dengan menggunakan data variabel independen yang sudah diketahui besarnya. Model ini digunakan untuk menguji pengaruh dua atau lebih variabel independen terhadap variabel dependen dengan skala pengukuran interval atau rasio dalam suatu persamaan linier (Indriantoro dan Supomo, 2009:211). Variabel independen terdiri dari tipe kepribadian, pengalaman, dan penerimaan perilaku disfungsional. Sedangkan variabel dependennya adalah audit judgment. 
Rumus regresi berganda yang digunakan adalah sebagai berikut:

$$
Y=a+b_{1} X_{1}+b_{2} X_{2}+b_{3} X_{3}+e
$$

Keterangan:

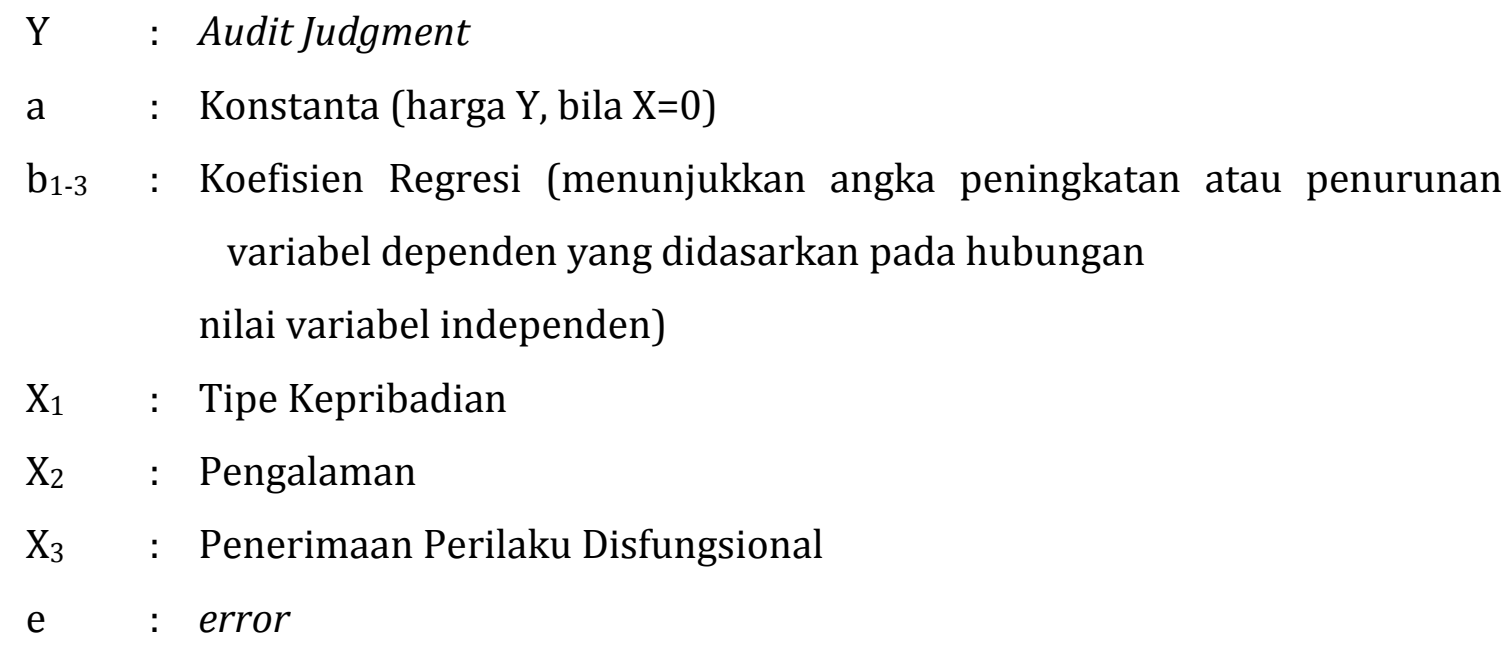

\section{PEMBAHASAN}

Peneliti mengambil sampel sebanyak 14 KAP dari keseluruhan KAP yang berada di wilayah Jakarta. Kuesioner yang disebarkan berjumlah 79 buah dan jumlah kuesioner yang kembali adalah sebanyak 63 buah kuesioner atau 79,7\%. Kuesioner yang tidak kembali sebanyak 16 buah atau 20,3\%, hal ini mungkin dikarenakan waktu penyebaran kuesioner yang kurang tepat. Kuesioner yang dapat diolah berjumlah 51 buah atau 64,5\%, sedangkan kuesioner yang tidak dapat diolah karena tidak memenuhi kriteria sebagai sampel dan tidak diisi secara lengkap oleh responden sebanyak 12 buah atau $15,2 \%$.

\section{Hasil Uji Statistik Deskriptif}

Berdasarkan hasil pengujian variabel tipe kepribadian jawaban minimum responden sebesar 20,00 dan maksimum sebesar 39,00, dengan rata-rata total jawaban 32,51 dan standar deviasi sebesar 4,154. Variabel pengalaman jawaban minimum responden sebesar 36,00 dan maksimum sebesar 50,00 dengan rata-rata total jawaban 43,29 dan standar deviasi sebesar 3,966. Variabel penerimaan perilaku disfungsional minimum responden sebesar 22,00 dan maksimum sebesar 57,00 dengan rata-rata total jawaban 42,39 dan standar deviasi sebesar 9,424. Sedangkan, variabel audit judgment minimum jawaban responden sebesar 34,00 dan maksimum 
sebesar 50,00 dengan rata-rata total jawaban 42,63 dan standar deviasi sebesar 3,924 .

\section{Hasil Uji Asumsi Klasik}

a. Hasil Uji Multikolonieritas

Berdasarkan hasil pengujian nilai tolerance $\geq 0.10$ dan nilai variance inflation factor (VIF) $\leq 10$. Dengan demikian, dapat disimpulkan bahwa model persamaan regresi tidak terdapat problem multikolonieritas dan dapat digunakan dalam penelitian ini (Ghozali, 2011).

b. Hasil Uji Normalitas

Berdasarkan hasil pengujian memperlihatkan penyebaran data yang berada disekitar garis diagonal dan mengikuti arah garis diagonal, ini menunjukkan bahwa model regresi telah memenuhi asumsi normalitas. Untuk lebih meyakinkan hasil uji grafik maka pada uji normalitas ini juga dilengkapi dengan uji statistik, yaitu dengan menggunakan Uji Kolmogorov-Smirnov (K-S) pada alpha sebesar 5\% berarti data yang gunakan normal. Dari tabel 4.15 di bawah ini terlihat bahwa nilai Kolmogorov-Smirnov sebesar 0,990 dengan nilai signifikansi diatas 0,05 yang berarti nilai residual terdistribusi secara normal.

\section{Tabel 1}

Hasil Uji Kolmogorov-Smirnov (K-S) One-Sample Kolmogorov-Smirnov Test

\begin{tabular}{|ll|r|}
\hline & & $\begin{array}{c}\text { Unstandardized } \\
\text { Residual }\end{array}$ \\
\hline $\mathrm{N}$ & Mean & 51 \\
Normal Parameters & & $0 \mathrm{E}-7$ \\
& Std. Deviation & 3.38727569 \\
& Absolute & .062 \\
Most Extreme Differences & Positive & .052 \\
& Negative & -.062 \\
Kolmogorov-Smirnov Z & & .441 \\
Asymp. Sig. (2-tailed) & & .990 \\
\hline
\end{tabular}

a. Test distribution is Normal.

b. Calculated from data.

Sumber: data diolah (2015)

c. Hasil Uji Heteroskedastisitas

Pengujian heteroskedastisitas dilakukan untuk menguji apakah dalam sebuah model regresi, terjadi ketidaksamaan varians dari residual dari satu 
pengamatan ke pengamatan yang lain. Jika varians dari residual dari suatu pengamatan ke pengamatan yang lain tetap, maka disebut homoskedastisitas.

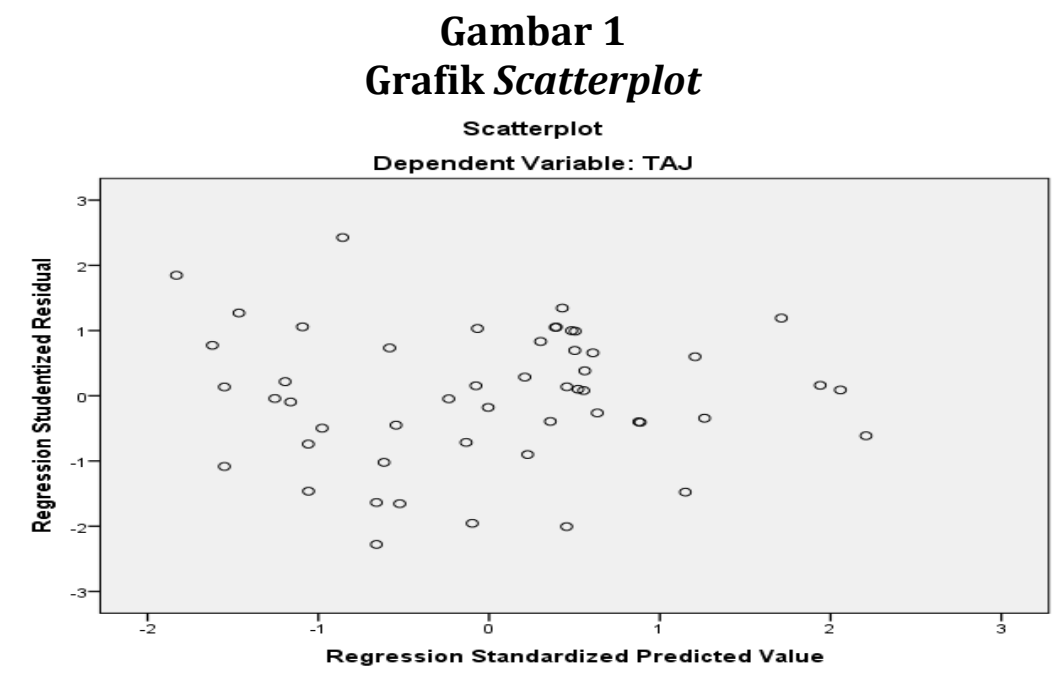

Sumber: Data primer yang diolah

Berdasarkan gambar 1, grafik scatterplot menunjukkan bahwa data tersebar di atas dan di bawah angka 0 (nol) pada sumbu Y dan tidak terdapat suatu pola yang jelas pada penyebaran data tersebut. Hal ini berarti tidak terjadi heteroskedastisitas pada model persamaan regresi, sehingga model regresi layak digunakan untuk memprediksi audit judgment berdasarkan variabel yang mempengaruhinya, yaitu tipe kepribadian, pengalaman dan penerimaan perilaku disfungsional.

Pengujian hipotesis dalam penelitian ini dilakukan dengan menggunakan model analisis regresi berganda (multiple regression analysis) dengan tingkat signifikansi $\alpha=0,05$.

$$
\mathrm{Y}=20,521+0,028 \mathrm{X}_{1}+0,372 \mathrm{X}_{2}+0,120+\varepsilon
$$

Dimana:

$\mathrm{Y}=$ Variabel terikat atau dependen (Audit Judgment)

$\mathrm{a}=$ Konstanta

$\mathrm{X} 1$ = Tipe Kepribadian

$\mathrm{X} 2$ = Pengalaman

X3 = Penerimaan Perilaku Disfungsional

$\varepsilon=$ error 
Tabel 2

Hasil Uji Koefisien Determinasi $\left(R^{2}\right)$ Variabel $X_{1}, X_{2}, X_{3}$ dan $Y$ Model Summary

\begin{tabular}{|l|r|r|r|r|}
\hline Model & \multicolumn{1}{|c|}{$\mathrm{R}$} & R Square & Adjusted R Square & $\begin{array}{c}\text { Std. Error of the } \\
\text { Estimate }\end{array}$ \\
\hline 1 & $.505^{\mathrm{a}}$ & .255 & .207 & 3.494 \\
\hline
\end{tabular}

a. Predictors: (Constant), TPPD, TP, TTK

Sumber: Data diolah (2015)

Tabel diatas menunjukkan variasi tipe kepribadian, pengalaman dan penerimaan perilaku disfungsional dapat menjelaskan 20,7 \% variasi variabel audit judgment. Sedangkan sisanya 79,3 \% dijelaskan oleh variabel-variabel lain di luar model penelitian, seperti kompleksitas tugas, kompetensi dan independensi.

\section{Hasil Uji Hipotesis}

a. Uji Signifikansi Parameter Individual (Uji t Statistik)

Tabel 3 Hasil Uji Statistik t Variabel $X_{1}, X_{2}, X_{3}$ dan $Y$

\begin{tabular}{|l|r|r|r|r|r|}
\hline \multirow{2}{*}{ Model } & \multicolumn{2}{|c|}{$\begin{array}{c}\text { Unstandardized } \\
\text { Coefficients }\end{array}$} & \multicolumn{1}{c|}{$\begin{array}{c}\text { Standardized } \\
\text { Coefficients }\end{array}$} & \multirow{2}{*}{ Sig. } \\
\cline { 2 - 4 } & \multicolumn{1}{|c|}{ B } & \multicolumn{1}{c|}{ Std. Error } & \multicolumn{1}{c|}{ Beta } & \\
\hline (Constant) & 20.521 & 6.915 & & 2.967 & .005 \\
TTK & .028 & .124 & .030 & .229 & .820 \\
TP & .372 & .126 & .376 & 2.943 & .005 \\
TPPD & .120 & .055 & .288 & 2.181 & .034 \\
\hline
\end{tabular}

a. Dependent Variable: TAJ

Sumber: Data diolah (2015)

Berdasarkan hasil uji regresi t pada tabel menunjukkan bahwa variabel tipe kepribadian tidak terbukti berpengaruh terhadap variabel dependen, yaitu audit judgment. Hal ini dapat dilihat dari nilai probabilitas untuk tipe kepribadian sebesar 0,820 (Sig < 0,05). Variabel pengalaman sebagai variabel independen terbukti berpengaruh terhadap variabel independen, yaitu pemberian audit judgment. Hal ini dapat terlihat dari nilai probabilitas signifikan untuk pengalaman sebesar 0,005 (sig < 0,05). Variabel penerimaan perilaku disfungsional sebagai variabel independen juga terbukti berpengaruh terhadap variabel independen, yaitu audit judgment. Hal ini dapat terlihat dari nilai probabilitas signifikan untuk penerimaan perilaku disfungsional sebesar $0,034(\operatorname{sig}<0,05)$. 
b. Uji Signifikasi Simultan (Uji Statistik F)

Uji statistik F dapat dilihat pada tabel jika nilai probabilitas lebih kecil dari 0,05 maka $\mathrm{H}_{\mathrm{a}}$ menolak $\mathrm{H}_{\mathrm{o}}$. Sedangkan jika nilai probabilitas lebih besar dari 0,05 maka $\mathrm{H}_{\mathrm{o}}$ diterima dan menolak $\mathrm{H}_{\mathrm{a}}$ (Ghozali, 2011). Uji statistik $\mathrm{F}$ dilakukan untuk mengetahui pengaruh semua variabel independen yang dimasukkan ke dalam variabel model regresi secara bersama-sama terhadap variabel dependen.

Hasil Uji Statistik Signifikasi Simultan (Uji F) dapat dilihat dalam tabel 4.18 berikut ini:

Tabel 4

Hasil Uji Statistik F

ANOVAa

\begin{tabular}{|l|r|r|r|c|c|}
\hline Model & Sum of Squares & \multicolumn{1}{c|}{ Df } & Mean Square & F & Sig. \\
\hline Regression & 196.240 & 3 & 65.413 & 5.359 & $.003^{\mathrm{b}}$ \\
1 Residual & 573.682 & 47 & 12.206 & & \\
Total & 769.922 & 50 & & & \\
\hline
\end{tabular}

a. Dependent Variable: TAJ

b. Predictors: (Constant), TPPD, TP, TTK

Sumber: Data diolah (2015)

Tabel 4 menunjukkan hasil uji statistik $\mathrm{F}$ terhadap variabel-variabel independen dan variabel dependen. Tabel tersebut menunjukkan bahwa tipe kepribadian, pengalaman dan penerimaan perilaku disfungsional secara simultan berpengaruh terhadap audit judgment. Hal tersebut dibuktikan dengan tingkat signifikansi 0,003 lebih kecil dari 0,05.

a. Tipe Kepribadian Tidak Berpengaruh Terhadap Audit Judgment.

Hasil uji koefisien regresi linear berganda menunjukkan bahwa variabel tipe kepribadian mempunyai tingkat signifikansi (p) sebesar 0,820 lebih besar dari $\alpha=5 \%$. Hal ini berarti menolak $\mathrm{Ha}_{1}$ bahwa tipe kepribadian berpengaruh terhadap audit judgment. Hasil penelitian ini memberikan bukti empiris bahwa adanya perbedaan tipe kepribadian A dan B tidak dapat mempengaruhi audit judgment yang dibuat oleh auditor. Auditor akan tetap memberikan judgment secara obyektif atas kesangsian laporan keuangan sesuai dengan Standar Akuntansi Keuangan di Indonesia tanpa dipengaruhi 
perbedaan tipe kepribadian masing-masing auditor. Ini berarti, auditor tidak mempertimbangkan aspek tipe kepribadian yang dimilikinya dalam membuat audit judgment. Kemungkinan yang terjadi adalah auditor mengedepankan sikap profesionalitas dalam pekerjaannya. Karena profesi auditor dibatasi oleh kode etik dan standar profesional. Auditor dengan tipe kepribadian A ataupun B dalam proses audit akan tetap bersikap profesional untuk membuat audit judgment. Artinya, tipe kepribadian tidak berpengaruh secara parsial terhadap proses pembuatan auditjudgment.

Hasil penelitian ini mendukung penelitian yang dilakukan oleh Kristianti (2012) yang menyebutkan bahwa masing-masing tipe kepribadian tidak memiliki perbedaan dalam hal pembuatan audit jugment. Artinya, tipe kepribadian tidak mempengaruhi pembuatan audit judgment. Namun, penelitian ini tidak mendukung hasil dari penelitian Pincus (1991) dan Kent et al., (2006) yang menyimpulkan bahwa tipe kepribadian yang dimiliki oleh seorang auditor mempengaruhi audit judgment yang dibuatnya secara signifikan.

b. Pengalaman Berpengaruh Terhadap Audit Judgment.

Hasil uji koefisien regresi linier berganda menunjukkan bahwa variabel pengalaman mempunyai tingkat signifikansi sebesar 0,005. Hal ini berarti menerima $\mathrm{Ha}_{2}$ sehingga dapat dikatakan bahwa pengalaman berpengaruh secara signifikan terhadap audit judgment karena tingkat signifikansinya lebih kecil dari 0,05. Hasil penelitian ini memberikan bukti empiris bahwa dengan bertambahnya pengalaman audit membuat auditor akan lebih bijak dalam membuat audit judgment. Pengalaman akan membantu auditor dalam menentukan sikap, memprediksi dan mendeteksi masalah. Pengalaman juga pada umumnya akan membantu auditor dalam menemukan kekeliruan di suatu perusahaan dan menyelesaikan kekeliruan tersebut.

Pengalaman yang dimiliki auditor dalam proses audit cenderung mempengaruhi auditor dalam membuat judgment, semakin banyak pengalaman yang dimilikinya membuat judgment yang diambil semakin baik dan etis. Begitupun sebaliknya, semakin auditor tidak memiliki pengalaman 
maka semakin buruk dan tidak etis pula judgment yang dibuatnya dalam proses audit. Artinya, pengalaman berpengaruh signifikan terhadap audit judgment yang dibuat seorang auditor.

Hasil penelitian ini mendukung penelitian Putri et al,. (2013), Arum (2008) serta Herliansyah dan Ilyas (2006) yang menyatakan bahwa pengalaman memiliki pengaruh yang signifikan terhadap judgment yang dibuat oleh auditor. Namun penelitian ini tidak mendukung hasil dari penelitian Gusti dan Ari (2008) yang menyimpulkan bahwa pengalaman tidak mempunyai pengaruh terhadap audit judgment.

c. Penerimaan Perilaku Disfungsional Berpengaruh Terhadap Audit Judgment.

Hasil uji hipotesis $\mathrm{Ha}_{3}$ menunjukkan bahwa penerimaan perilaku disfungsional berpengaruh terhadap audit judgment. Hal ini dapat dibuktikan dengan tingkat signifikansi 0,034 . Hal ini berarti menerima $\mathrm{Ha}_{3}$ sehingga dapat dikatakan bahwa penerimaan perilaku disfungsional berpengaruh secara signifikan terhadap audit judgment karena tingkat signifikansinya lebih kecil dari 0,05. Hal ini dapat dijelaskan bahwa semakin auditor menerima perilaku disfungsional maka judgment yang dibuatnya beresiko lebih buruk dari pada auditor yang menolak perilaku disfungsional. Auditor yang mengerjakan audit secara terprogram dan sesuai prosedur serta mengerjakan setiap proses audit dengan benar akan cenderung menolak perilaku disfungsional sehingga akan menghasilkan judgment yang lebih baik dari pada yang menerima perilaku disfungsional. Sedangkan audior yang merasa tertekan dengan sistem pengendalian dan menghalalkan segala cara untuk menyelesaikan pekerjaan audit akan cenderung menerima perilaku disfungsional dan membuat audit judgment yang juga cenderung tidak etis. Ini menunjukkan bahwa penerimaan perilaku disfungsional yang dilakukan oleh auditor berpengaruh signifikan terhadap audit judgment yang dibuatnya.

Hasil penelitian ini mendukung penelitian yang dilakukan oleh Kristianti (2012) serta Donelly et al., (2003) yang menyebutkan bahwa auditor yang menerima perilaku disfungsional memiliki perbedaan dalam hal membuat audit judgment dengan auditor yang menolak perilaku 
disfungsional, semakin sering auditor menerima perilaku disfungsional maka semakin buruk dan tidak etis judgment yang akan dibuatnya. Begitupun sebaliknya, semakin auditor tidak menerima perilaku disfungsional maka semakin baik pula kualitas audit judgment yang dibuatnya.

d. Pengaruh Tipe Kepribadian, Pengalaman dan Penerimaan Perilaku Disfungsional Terhadap Audit Judgment.

Pengujian statistik pada hipotesis ( $\left.\mathrm{Ha}_{4}\right)$ menunjukkan bahwa tipe kepribadian, pengalaman dan penerimaan perilaku disfungsional berpengaruh secara simultan terhadap audit judgment. Pada tabel 4.18 dapat dilihat nilai uji $\mathrm{F}$ variabel tipe kepribadian, pengalaman dan penerimaan perilaku disfungsional auditor terhadap audit judgment sebesar 5.359 dengan melihat nilai signifikansi dibawah 0.05 yaitu sebesar 0.003 . Dengan demikian hipotesis alternatif yang menyatakan bahwa tipe kepribadian, pengalaman dan penerimaan perilaku disfungsional berpengaruh secara simultan terhadap audit judgment dapat diterima.

Hal ini menunjukkan bahwa tipe kepribadian, pengalaman dan penerimaan perilaku disfungsional dihadapkan secara bersama-sama pada audit judgment, maka akan semakin banyak juga pertimbangan yang dilakukan oleh auditor. Pertimbangan-pertimbangan yang dihadapkan secara bersamaan tersebut kemudian berpengaruh secara simultan terhadap audit judgment yang dibuat oleh auditor.

Hasil penelitian ini mendukung penelitian yang dilakukan oleh Kristianti (2012), Pincus (1991), Kent et al., (2006), Putri et al., (2013), Arum (2008), Herliansyah dan Ilyas (2006) serta Donelly et al., (2003).

\section{KESIMPULAN}

Berdasarkan pembahasan sebelumnya maka penelitian ini dapat disimpulkan:

1. Hasil uji regresi linear berganda menunjukkan bahwa tipe kepribadian tidak berpengaruh secara signifikan terhadap audit judgment. Hal ini dapat dijelaskan oleh besarnya tingkat signifikasi variabel yaitu sebesar 0,820 . Hasil penelitian ini mendukung penelitian yang dilakukan oleh Kristianti (2012). Namun, penelitian ini tidak mendukung hasil dari penelitian Pincus (1991) dan Kent et al., (2006) 
yang menyimpulkan bahwa tipe kepribadian yang dimiliki oleh seorang auditor mempengaruhi audit judgment yang dibuatnya secara signifikan.

2. Hasil uji regresi berganda menunjukkan bahwa pengalaman berpengaruh secara signifikan terhadap audit judgment. Hal ini dapat dijelaskan oleh besarnya tingkat signifikansi variabel 0,005. Hasil penelitian ini mendukung penelitian Putri et al. (2013), Arum (2008) serta Herliansyah dan Ilyas (2006). Namun begitu penelitian ini tidak mendukung hasil dari penelitian Gusti dan Ari (2008) yang menyatakan bahwa pengalaman tidak berpengaruh secara signifikan terhadap audit judgment.

3. Hasil uji regresi berganda menunjukkan bahwa penerimaan perilaku disfungsional berpengaruh secara signifikan terhadap audit judgment. Hal ini dapat dijelaskan oleh besarnya tingkat signifikansi variabel 0,034. Hasil penelitian ini mendukung penelitian dari Kristianti (2012) serta Donelly et al., (2003).

4. Hasil uji regresi linear berganda menunjukkan bahwa tipe kepribadian, pengalaman dan penerimaan perilaku disfungsional berpengaruh secara simultan dan positif terhadap audit judgment. Hasil penelitian ini mendukung penelitian yang dilakukan oleh oleh Kristianti (2012), Pincus (1991), Kent et al., (2006), Putri et al., (2013), Arum (2008), Herliansyah dan Ilyas (2006) serta Donelly et al., (2003).

\section{REFERENSI}

Agoes Sukrisno. 2012. “Auditing (Penunjuk Praktis Pemeriksaan Akuntan oleh Akuntan Publik)", Jilid 1, Edisi keempat. Salemba Empat, Jakarta.

Ajzen, I., 1991. "The Theory of Planned Behavior", Organizational Behavior and Human Decision Processes 50, 179-211.

Ananing. 2006. "Pengaruh Pengalaman Terhadap Peningkatan Keahlian Auditor Dalam Bidang Auditing", Jurnal Fakultas Ekonomi Universitas Indonesia.

Arens, Alvin A, Randal J. Elder, Mark S. Beasley. 2010. "Auditing and Assurance Services An Integrated Approach", 13th edition, Pearson Education Inc, Upper Saddle River, New Jersey.

Arum, Enggar Diah Puspa. 2008. "Pengaruh Persuasi atas Preferensi Klien dan Pengalaman Audit Terhadap Pertimbangan Auditor Dalam Mengevaluasi Bukti Audit", Universitas Jambi, Jurnal akuntansi dan keuangan Indonesia. Vol.5 No.2 
Batubara, Khairudin. 2009. "Pengaruh Pengalaman dan Pengetahuan Aparat Pengawas Intern Pemerintah Terhadap Pendeteksian Penyimpangan dengan Intuisi Sebagai Variabel Intervening Pada Inspektorat Kabupaten Deli Serdang", Tesis Pascasarjana Universitas Sumatera Utara, Medan.

Boynton William C, Raymond N. Johnson, Walter G. Kell. 2006. “Modern Auditing: Assurance Services and The Integrity of Financial Reporting", 8th edition, John Wiley\&Sons Inc, United States of America.

Donelly, David P., Jeffrey J.Q, dan David O., 2003. "Auditor Acceptance of Dysfunctional Audit Behavior: An Explanatory Model Using Auditors' Personal Characteristics". Journal of Behavioral Research In Accounting: vol. 15 : 87-107.

Fatah, Abdul Arrozaky. 2013. "Pengaruh Kompleksitas Tugas, Tekanan Anggaran Waktu dan Pengalaman Terhadap Audit Judgment, Skripsi UIN Syarif Hidayatullah Jakarta.

Gaballa, Azza S.M dan Zhou Ning. 2010. "An Analytical Study of The Effects Of Experience On Performance Of The External Auditor", International Conference on Business and Economics Research, China.

Gusti, Maghfirah dan Syahril Ari. 2008. "A Research Note on The Effect of Gender and Task Complexity on Audit Judgment", Simposium Nasional Akuntansi IX, Pontianak.

Ghozali, Imam. 2011. "Aplikasi Analisis Multivariate Dengan Program SPSS", Edisi Ketiga, Badan Penerbit Universitas Diponegoro, Semarang.

Haryanti, Sri, Caecelia. 2013. "Pengaruh Pengalaman dan Keahlian Auditor Terhadap Strktur Pengetahuan Tentang Kekeliruan Auditor", Jurnal Ilmiah Dinamika Ekonomika dan Bisnis Vol. 1, No. 1, Universitas 17 Agustus 1945.

Harini, Dwi, Agus Wahyudin, Indah Anisyukurlillah. 2009. "Analisis Penerimaan Auditor Atas Dysfunctional Audit Behavior : Sebuah Pendekatan Karakteristik Personal Auditor", Simposium Nasional Akuntansi XIII, Purwokerto.

Herliansyah, Yhudi dan Meifida Ilyas. 2006. "Pengaruh Pengalaman auditor terhadap penggunaan bukti tidak relavam dalam auditor judgment", Simposium Nasional Akuntansi IX, Padang, Agustus. 
Holmes, Arthur W. dan Burns, David C. "Auditing: Norma dan Prosedur". Edisi Kesembilan. Jilid 1. Erlangga. Jakarta. 1996.

Ikatan Akuntan Indonesia (IAI) Kompartemen Akuntan Publik. 2001. "Standar Profesional Akuntan Publik", Salemba Empat, Jakarta.

Indriantoro, Nur dan Bambang Supomo. 2009. " Metodologi Penelitian Bisnis Untuk Akuntansi dan Manajemen Edisi Pertama", BPFE, Yogyakarta.

Institut Akuntan Publik Indonesia. 2009. "Kode Etik Profesi Akuntan Publik”, Jakarta Jamilah, Siti, Zaenal Fanani dan Grahita Chandrarin. 2007. "Pengaruh Gender, Tekanan Ketaatan, dan Kompleksitas Tugas terhadap Audit Judgment”, Simposium Nasional Akuntansi X, Universitas Hasanudin, Makasar, Juli.

Jaffar, Nahariah, Hasnah Haron, Takiah Mohd Iskandar, Arfah Salleh. 2011. "Fraud Risk Assessment and detection Fraud: The Moderating Effect of Personality". International Journal of Business and Management, Vol. 6, No. 7, 40-50.

Justiana, Dita. 2010. "Pengaruh Etika, Independensi, Pengalaman Dan Keahlian Auditor Terhadap Opini audit", Skripsi UIN Syarif Hidayatullah, Jakarta.

Kent, Pamela, Lois Munro, Tony Gambling. 2006. "Psychological Characteristics Contributing To Expertise In Audit Judgment", International Journal Of Auditing, Vol. 10, Issue. 2.

Kristianti, Ika. 2012. "Pengaruh Tipe Kepribadian dan Penerimaan Perilaku Disfungsional Terhadap Audit Judgment", Tesis Universitas Kristen Satya Wacana, Jawa Tengah.

Mabruri, Havidz dan Winarna, Jaka. 2010. "Analisis Faktor-Faktor yang Mempengaruhi Kualitas Hasil Audit di Lingkungan Pemerintah Daerah", Jurnal Simposium Nasional Akuntansi XIII Purwokerto.

Mahardini, Nyoman Mita, Edy Sujana, Made Pradana Adiputra. 2014. "Pengaruh Etika Profesi Dan Tekanan Anggaran Waktu Terhadap Perilaku Disfungsional Auditor", Jurusan Akuntansi Program S1 Vol:2 No:1, Universitas Pendidikan Ganesha, Bali.

Myers-Briggs "Type Indicator". Wikipedia, the free encyclopedia. May 20, 2014. http://www.en.wikipedia.org

Nasution, Hafifah dan Fitriany. 2012. "Pengaruh Beban Kerja, Pengalaman Audit dan Tipe Kepribadian Terhadap Skeptisme Profesional Dan Kemampuan Auditor 
| PENGARUH TIPE KEPRIBADIAN, PENGALAMAN DAN PENERIMAAN...

Dalam Mendeteksi Kecurangan", UIN Syarif Hidayatullah Jakarta dan Universitas Indonesia.

Pincus, Karen V. 1991. "Audit Judgment Confidence", Behavioral Research In Accounting Journal Vol. 3, University Of Southern California

Prastiwi , Andri dan Destriana Kurnia Kreshastuti. 2014. “Analisis Faktor-Faktor yang Mempengaruhi Intensi Auditor untuk Melakukan Tindakan Whistleblowing", Diponegoro Journal of Accounting Volume 3, Nomor 2, Halaman 1-15.

Pratiwi, Dita Agustia. 2014. "Pengaruh Profesionalisme, Pertimbangan Etis dan Personal Cost terhadap Intensi Melakukan Whistleblowing”, Skripsi Fakultas Ekonomi dan Bisnis UIN Syarif Hidayatullah Jakarta, Jakarta.

Putri, Pritta Amina dan Herry Laksito. 2013. "Pengaruh Lingkungan Etika, Pengalaman Auditro dan Tekanan Ketaatan Terhadap Kualitas Audit Judgment", Diponegoro Jurnal Of Accounting, Universitas Diponegoro, Semarang.

Rotter, J. B., 1966. “Generalized Expectancies for Internal Versus External Control of Reinforcement",Psychological Monographs, 80(1, Whole No. 609).

Silaban, Adanan. 2009. "Perilaku Disfungsional Auditor Dalam Pelaksanaan Program Audit", Disertasi Universitas Diponegoro, Semarang.

Silalahi, Paulus Sem. 2013. "Pengaruh Etika, Kompetensi, Pengalaman Audit dan Situasi Audit Terhadap Skeptisme Professional Auditor", Jurnal Ekonomi Vol. 21 No.3, September, Universitas Riau.

Sujana, Edy dan Tjiptohadi Sawarjuwono. 2006. "Perilaku Disfungsional Auditor: Perilaku yang Tidak Mungkin Dihentikan", Jurnal Bisnis dan Akuntansi, Vol.8 No.3:247-259, Bali.

Sulistomo, Akmal. 2012. "Persepsi Mahasiswa Akuntansi terhadap Pengungkapan Kecurangan (Studi Empiris pada Mahasiswa Akuntansi Undip dan UGM)". Skipsi Tidak Dipublikasikan. Program Sarjana Universitas Diponegoro.

The Oxford English Dictionary Volume III. 1978. Oxford University Press, Great Britain.

Turban, Efraim., Jay E. Aronson, dan Ting - Peng Liang. 2005. "Decision Support Systems dan Intelligent Systems". Edisi Ketujuh. Penerbit Dani, Yogyakarta.

Wibowo, Ery. "Pengaruh Gender, Pemahaman Kode Etik Profesi Akuntan Terhadap Auditor Judgment", Jurnal Akuntansi Universitas Muhamadiyah 